\title{
Enlisting the Ixodes scapularis Embryonic ISE6 Cell Line to Investigate the Neuronal Basis of Tick-Pathogen Interactions
}

\author{
Lourdes Mateos-Hernández ${ }^{1}\left(\right.$, Natália Pipová ${ }^{2}{ }^{\circledR}$, Eléonore Allain ${ }^{1}$, Céline Henry ${ }^{3}$, Clotilde Rouxel $^{1}$, \\ Anne-Claire Lagrée ${ }^{1}{ }^{(0)}$, Nadia Haddad ${ }^{1}$, Henri-Jean Boulouis ${ }^{1}$, James J. Valdés ${ }^{4,5}$, Pilar Alberdi ${ }^{6,7}{ }^{1}$, \\ José de la Fuente ${ }^{6,8}\left(\mathbb{D}\right.$, Alejandro Cabezas-Cruz ${ }^{1, *}$ and Ladislav Šimo ${ }^{1, *}$ (D)
}

1 UMR BIPAR, Laboratoire de Santé Animale, ANSES, INRAE, Ecole Nationale Vétérinaire d'Alfort, Paris-Est Sup, 94700 Maisons-Alfort, France; lourdes.mateos@vet-alfort.fr (L.M.-H.); eleonore.allain@hotmail.fr (E.A.); clotilde.rouxel@vet-alfort.fr (C.R.); anne-claire.lagree@vet-alfort.fr (A.-C.L.); nadia.haddad@vet-alfort.fr (N.H.); henri-jean.boulouis@vet-alfort.fr (H.-J.B.)

2 Faculty of Science, Pavol Jozef Šafarik University in Košice, 04180 Košice, Slovakia; kokosova.natalia@gmail.com

3 AgroParisTech, Micalis Institute, Université Paris-Saclay, PAPPSO, INRAE, 78350 Jouy-en-Josas, France; celine.henry@inrae.fr

4 Institute of Parasitology, Biology Centre of the Czech Academy of Sciences, Branisovska 31, 37005 Ceske Budejovice, Czech Republic; valdjj@gmail.com

5 Department of Virology, Veterinary Research Institute, Hudcova 70, 62100 Brno, Czech Republic

6 SaBio Instituto de Investigación en Recursos Cinegéticos IREC-CSIC-UCLM-JCCM, Ronda de Toledo s/n, 13005 Ciudad Real, Spain; maria.alberdi@uclm.es (P.A.); josedejesus.fuente@uclm.es (J.d.l.F.)

7 Neuroplasticity and Neurodegeneration Group, Regional Centre for Biomedical Research (CRIB), Ciu-dad Real Medical School, University of Castilla-La Mancha, 13071 Ciudad Real, Spain

check for

updates

Citation: Mateos-Hernández, L.; Pipová, N.; Allain, E.; Henry, C.; Rouxel, C.; Lagrée, A.-C.; Haddad, N.; Boulouis, H.-J.; Valdés, J.J.; Alberdi, P.; et al. Enlisting the Ixodes scapularis Embryonic ISE6 Cell Line to Investigate the Neuronal Basis of Tick-Pathogen Interactions. Pathogens 2021, 10, 70. http://doi.org/ 10.3390/pathogens10010070

Received: 16 December 2020 Accepted: 8 January 2021 Published: 14 January 2021

Publisher's Note: MDPI stays neutral with regard to jurisdictional clai$\mathrm{ms}$ in published maps and institutional affiliations.

Copyright: $\odot 2021$ by the authors. Licensee MDPI, Basel, Switzerland. This article is an open access article distributed under the terms and conditions of the Creative Commons Attribution (CC BY) license (https:// creativecommons.org/licenses/by/ $4.0 /)$.
8 Center for Veterinary Health Sciences, Department of Veterinary Pathobiology, Oklahoma State University, Stillwater, OK 74078, USA

* Correspondence: alejandro.cabezas@vet-alfort.fr (A.C.-C.); ladislav.simo@vet-alfort.fr (L.Š.); Tel.: +33-6-31-23-51-91 (A.C.-C.); +33-1-49-77-46-52 (L.Š.)

\begin{abstract}
Neuropeptides are small signaling molecules expressed in the tick central nervous system, i.e., the synganglion. The neuronal-like Ixodes scapularis embryonic cell line, ISE6, is an effective tool frequently used for examining tick-pathogen interactions. We detected 37 neuropeptide transcripts in the I. scapularis ISE6 cell line using in silico methods, and six of these neuropeptide genes were used for experimental validation. Among these six neuropeptide genes, the tachykinin-related peptide (TRP) of ISE6 cells varied in transcript expression depending on the infection strain of the tick-borne pathogen, Anaplasma phagocytophilum. The immunocytochemistry of TRP revealed cytoplasmic expression in a prominent ISE6 cell subpopulation. The presence of TRP was also confirmed in A. phagocytophilum-infected ISE6 cells. The in situ hybridization and immunohistochemistry of TRP of I. scapularis synganglion revealed expression in distinct neuronal cells. In addition, TRP immunoreaction was detected in axons exiting the synganglion via peripheral nerves as well as in hemal nerve-associated lateral segmental organs. The characterization of a complete Ixodes neuropeptidome in ISE6 cells may serve as an effective in vitro tool to study how tick-borne pathogens interact with synganglion components that are vital to tick physiology. Therefore, our current study is a potential stepping stone for in vivo experiments to further examine the neuronal basis of tick-pathogen interactions.
\end{abstract}

Keywords: Ixodes scapularis ISE6 cell line; neuropeptides; Anaplasma phagocytophilum; synganglion

\section{Introduction}

The North American black-legged deer tick Ixodes scapularis and the European castor-bean tick Ixodes ricinus are both medically important arthropod vectors. These two allopatric tick species are well recognized for transmitting a wide spectra of bacterial, viral, and protozoan pathogens [1,2]. Both tick species infect hosts with the bacterium Anaplasma phagocytophilum, 
which is an emerging tick-borne pathogen (TBP) that causes granulocytic anaplasmosis and tick-borne fever [3]. Therefore, a tick control strategy is needed for A. phagocytophilum, since the infection rate for humans and animals increase yearly in the United States, Europe, Africa, and Asia [4]. However, developing effective tick control strategies to prevent $A$. phagocytophilum transmission requires a better understanding of specific interactions between this pathogen and the tick [5]. To address this limitation, researchers may utilize the I. scapularis embryo-derived cell line, ISE6, as an in vitro analytical tool, since ISE6 cells are commonly used in propagating various TBPs [6-10]. The ISE6 cell line is successful in isolating and analyzing tick-borne bacteria (i.e., Rickettsia, Ehrlichia, Borrelia, and Anaplasma) [8,10-14], as well as propagating arboviruses and vector-borne flaviviruses (i.e., Semiliki Forest, Hazara, or the Langat viruses) $[15,16]$.

The I. scapularis ISE6 cell line was established almost three decades ago [17], but its tissue origin, or biological background, remains ambiguous. However, proteomics and transcriptomics analyses of ISE6 cells reveal a mixture of neuronal and immune responseassociated markers $[18,19]$. Although the potential neuronal function of ISE6 cells remains untested, the expression of multiple neuron-associated proteins is confirmed [18]. For instance, Slit molecules promote neuronal axon guidance, cell mobility and permeability, and viral infection. The Roundabout protein 2, the transmembrane receptor for Slit, protects ISE6 cells from A. phagocytophilum infection [20]. Morphologically, in vivo exposure of ISE6 cells to the tick hemocoel triggers a neuron-like phenotype [18]. Immune activators carried by A. phagocytophilum also cause an enhanced pathogenic resistance in ISE6 cells via a typical immune cell memory-like property known as immune priming [21,22]. Specifically, ISE6 cells primed with lipids 1-palmitoyl-2-oleoyl-sn-glycero-3-phosphoglycerol and 1-palmitoyl-2-oleoyl diacylglycerol activate the immune deficiency pathway to reduce the A. phagocytophilum burden compared with naïve cells [22]. Therefore, the ISE6 cell population is composed of neuron-like and hemocyte-like subpopulations [18,19,21], although the neuron-like phenotype is predominant [18].

A. phagocytophilum infects vertebrate granulocytes, whereas tick infection sites include the midgut, hemocytes, and salivary glands [3]. Although pathogen infection may increase tick fitness and survival, rather than cause harm [23], several studies using "omics" technologies reveal that $A$. phagocytophilum infection induces both transcriptional reprograming and protein-level changes in vertebrate and arthropod host cells [24-27]. The genetic and molecular alterations in ticks coincide with the multi-host adaptation of A. phagocytophilum $[28,29]$. The main cellular components and processes affecting ticks by $A$. phagocytophilum infection are the cytoskeleton, immunity, epigenetics, apoptosis, and metabolism $[25-27,30,31]$. Recent studies also suggest that $A$. phagocytophilum modulates complex behavioral responses in infected ticks [32-35]. Although the capacity of A. phagocytophilum to manipulate cellular processes is well established, the interaction of specific signaling molecules within the tick central nervous system, i.e., the synganglion, is overlooked. The first report regarding a bacterial pathogen infecting tick synganglion was from the Ehrlichia muris-like agent, a closely related bacterium to A. phagocytophilum [36]. The cortical zone of I. scapularis synganglion was heavily infected when fed with Ehrlichiainfected hamsters that indicated pathogen crossing of tick synganglion barriers [36].

Neuropeptides are expressed predominantly in multiple tick synganglion neurons $[37,38]$. These small peptide molecules, along with their cognate $G$ protein-coupled receptors, are important for invertebrate physiology, since their signaling pathways regulate key processes in reproduction, development, growth, and behavior $[39,40]$. Neuropeptidergic cells synthesize the neuropeptide precursor, called prepropeptide that is usually composed of multiple copies of the same (or similar) neuropeptides. The prepropeptide signal peptide drives transportation for cleavage of the prepropeptide into smaller, mature neuropeptides. Then, these mature neuropeptides are packed into secretory vesicles that are eventually transported to axon terminals for exocytosis [41]. The number of neuropeptide-encoding genes among invertebrates is more or less the same; however, their specific biological functions may differ among particular taxa [42]. Theoretically, the I. scapularis genome 
consists of approximately 100 neuropeptides encoded by at least 34 genes that correspond to invertebrate neuropeptide orthologs [37,43]. Tick neuropeptides are identified with immunohistochemistry, proteomics, and genomics $[37,38,44,45]$, but their function is almost exclusively implicated by discovering their transport pathways and/or the localization of their cognate receptors in target organ(s) $[37,46,47]$. Tachykinin-related peptides (TRP) constitute a large family of pleiotropic neuropeptides found across bilaterians [48]. On the one hand, vertebrate TRPs play important roles in pain, inflammation, sensory processes, immune systems, gut function, or hormonal regulation [48]. On the other hand, invertebrate TRPs are known for regulating the central nervous system and gut function, while olfactory processing, locomotion, food seeking, vasodilatation, nociception, and metabolic stress are also described [48].

For our current study, we confirmed the presence of an entire Ixodes neuropeptidome in ISE6 cells that led to several questions. Are neuropeptide-expressing ISE6 cells peptidergic neurons? Are Ixodes TRPs expressed in vivo (i.e., I. scapularis synganglion)? How are Ixodes TRPs respectively distributed in vitro versus in vivo? Given that A. phagocytophilum induces transcriptional reprograming in ticks [24-26], will infection affect Ixodes trp gene expression? The cumulative answers to these questions propose that ISE6 cells may serve as an effective in vitro tool for studying the nature of tick neuropeptidergic cells and their interactions with various TBPs.

\section{Results}

\subsection{Neuropeptidome of ISE6 Cells}

Extensive BLAST searches in the ISE6 genome predict 38 distinct genome-based neuropeptide genes and their representative genomic scaffolds (Table 1). The presence of 37 neuropeptide transcripts was also confirmed in the ISE6 Sequence Read Archive (SRA) databases (BioProject: PRJNA239331). The transcript for natalisin was the only neuropeptide not detected in our in silico searches (Table 1). We also failed to experimentally amplify the natalisin transcript using three different sets of primers (Supplementary Table S1). Then, six of the SRA-confirmed neuropeptides (i.e., sulfakinin, kinin, CCHamide, short neuropeptide F, and FGLamide-related allatostatin) were selected for qRT-PCR validation using RNA extracted from ISE6 cells (Supplementary Figure S1).

\subsection{Structure of the Gene-Encoding Ixodes TRP}

The ISE6 genome BLAST yielded a predicted transcript (VectorBase accession number ISCI008383) encoding a putative TRP. The I. ricinus TRP transcript (GenBank accession number MW082607) was molecularly identified in this study. Nucleotide and protein alignments of the I. scapularis TRP (ISCI008383) with I. scapularis TRP EST (EL516783) and I. ricinus TRP (MW082607) reveal an incorrect computational prediction of ISCI008383. Specifically, the $5^{\prime}$-end of ISCI008383 is incomplete with an incorrect translated putative signal peptide. The $3^{\prime}$-end reading frame is also shifted, causing an improper conceptual TRP translation (Supplementary Figure S2). A BLAST using the I. scapularis EST (EL516783) encoding TRP, against the ISE6 genome confirms a relationship to the PKSA02005591.1 scaffold, resulting in a better representation of the I. scapularis TRP genomic organization (Figure 1A). In ISE6 cells genome, the I. scapularis trp gene (Figure 1A) is composed of four exons $(\approx 140,87,328$, and $170 \mathrm{bp})$ interrupted by three introns (189857, 5018, and $1862 \mathrm{bp})$. The I. scapularis trp ORF is $492 \mathrm{bp}$, spanning exons 2-4 (Figure 1A). 
A

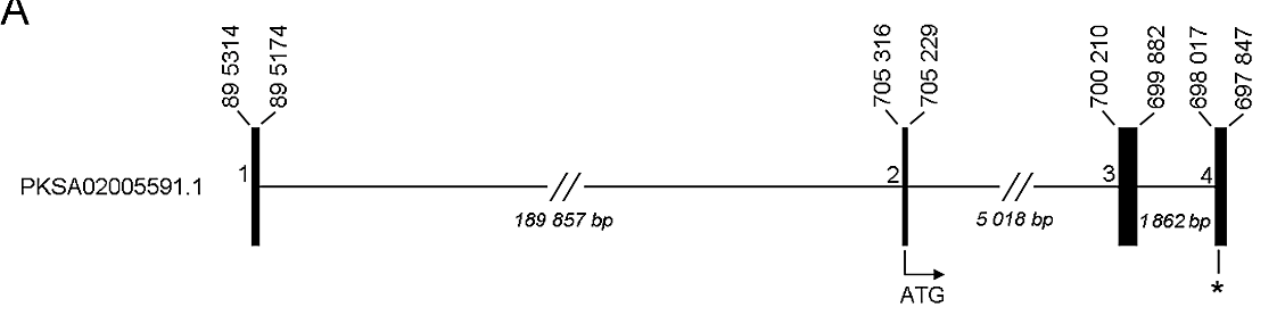

B
I.scapularis I.ricinus

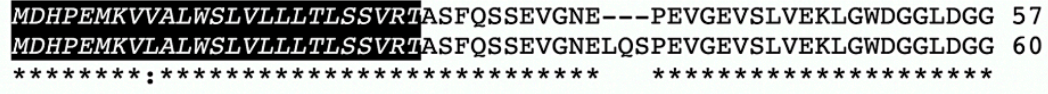
I.scapularis I.ricinus
DDLEIAAAADDEKRAFHAMRGKKDDPSLDWDEADKRAFHAMRGKRLLAPASVDSFIAOLR 11 DDLEIAAAADDE KRAFHAMRGKKDDPSLDWDEADKRAFHAMRGRRLLAPASVDSFIAQLR 120 $* * * * * * * * * * * * * * * * * * * * * * * * * * * * * * * * * * \pi * * * * * * * * *: * * * * * * * * * * * * * * * * * *$
I.scapularis I.ricinus
AVLOGKRGSGFFGMRGKRMSRTPGKEHPRSTFVATRGRRSVLSEAESRPYY 169 RAVLQGKRGSGFFGMRGKRMSRTPNKEHPRSTFVATRGRRSVLSEAESRPYY 172 $* * * * * * \pi * * * * * * * * * * * * \pi * * * * * * . * * * * * * * * * * * * * * * \pi * * * * * * * * * * * * * *$

C

I. scapularis

TRP1 ( 2 copies)

I. scapularis

TRP2

I. scapularis

TRP 3

I. ricinus

I. ricinus

TRP1 (2 copies)

I. ricinus

$R$. sanguineus

$R$. sanguineus

TRP2

TRP 3

TRP1 (2 copies)

$R$. sanguineus

TRP2

TRP 3

R. microplus

R. microplus

TRP1 (2 copies)

R. microplus

D. silvarum

TRP2

TRP 3

TRP1 (2 copies)

D. silvarum

TRP2

D. silvarum

TRP 3

V. destructor

TRP 1

$V$. destructor

TRP2

V. destructor

TRP 3

D. melanogaster TRP1

D. melanogaster TRP2

D. melanogaster TRP3

D. melanogaster TRP4

D. melanogaster TRP5

D. melanogaster TRP6

F-X1-G/A-X3-Ramide
GSGFFGMRamide
MSRTPGKEHPRTFVATRamide
AFHAMRamide
GSGFFGMRamide
MSRTPNKEHPRTFVATRamide
AFHAMRamide
GSGFFMRamide
QLRNGHKSSRTKVASRamide
AFHAMRamide
GSGFFGMRamide
QLRNGQKSSRTKFVAR Ramide
AFHAMRamide
GSGFFMRamide
AFHAMRamide
AMRNGHKSSRAKFASRamide
AAPFHAMRamide
GSFFGMRamide
APTSSFIGMRamide
APLAFVGRamide
APTGFTGMRamide
APVNSFVGRamide
PQRFADFNSKFVAVRamide
APNGFLGMRamide

Figure 1. Genomic organization and open reading frame of Ixodes tachykinin-related peptide (TRP). (A) Exon/intron organization of I. scapularis trp in the ISE6 genome. Horizontal lines represent introns, while vertical lines represent exons (numbered). The ATG is the translation initiation signal, and the asterisk represent the stop codon. (B) Protein sequence alignment of I. scapularis (EL516783) and I. ricinus (MW082607) TRP prepropeptide sequences. The putative signal peptide at the amine terminus is in italics with a black background. Putative mature peptides are in bold fonts. Dibasic cleavage sites are underlined and the canonical amidation signal is in a gray background. Asterisk, single dot and double dot indicate identical, similar, and different amino acid residues, respectively. (C) An alignment showing the consensus of I. scapularis, I. ricinus, $R$. sanguineus, $R$. microplus, D. silvarum, V. destructor, and D. melanogaster mature TRP neuropeptides. The F and $\mathrm{R}$ amino acids residues of TRP F- $x_{1}-\mathrm{G} / \mathrm{A}-\mathrm{x}_{3}$-Ramide motif are highlighted in a red background. R. sanguineus, R. microplus, and D. silvarum TRPs were predicted from GenBank Accession no. XP_037516719.1, XP_037279114.1, XP_037573036.1 respectively. $V$. destructor TRPs were extracted from Jiang et al. [49] and D. melanogaster TRPs were predicted from GenBank Accession no. CG14734.

The translated TRP ORF of I. scapularis (169 residues) and I. ricinus (172 residues) share $96.5 \%$ amino acid identity (Figure 1B). The TRP prepropeptide contains dibasic cleavage sites for three putative TRPs (plus one repeat) for both tick species that are characterized by 
a general conserved carboxy-terminus motif, F- $x_{1}-\mathrm{G} / \mathrm{A}-\mathrm{x}_{3}$-Ramide (Figure 1B,C). This TRP motif is typical for other tick species such as Rhipicephalus sanguineus, Rhipicephalus microplus, and Dermacentor silvarum, as well as the parasitic mite Varroa destructor [49] and the fruit fly Drosophila melanogaster TRPs (Figure 1C). I. scapularis, I. ricinus, R. sanguineus, R. microplus and D. silvarum share identical TRP1 and TRP2 amino acid sequence (Figure 1C).

\subsection{Expression of ISE6 TRP in Response to A. phagocytophilum Infection}

Compared to uninfected ISE6 cells (control), A. phagocytophilum infection causes disparate trp transcript levels that are strain-dependent (Figure 2A). Specifically, trp levels significantly decrease 0.5 -fold in ISE6 cells infected with human strain NY18, but they significantly increase 2.5 -fold with bovine strain BV49. No significant changes in trp transcript levels were detected in ISE6 cells infected with A. phagocytophilum ovine strain NV2Os (Figure 2A). Therefore, A. phagocytophilum NV2Os was selected to infect ISE6 cells for subsequent immunocytochemistry (ICC) detection of TRP, since trp transcript levels were stable (Figure $2 \mathrm{~B}-\mathrm{G}$ ). Immunochemical analyses were facilitated by an antibody against the D. melanogaster neuropeptide natalisin (DromeNTL4) [50], (also see Section 4) that is a sister group of TRP. The DromeNTL4 C-terminal sequence (FPATRamide) is highly similar to the Ixodes TRP3 (FVATRamide) (Figure 1C). Therefore, the term TRP-like immunoreaction (TRP-like IR) is used hereafter.

A

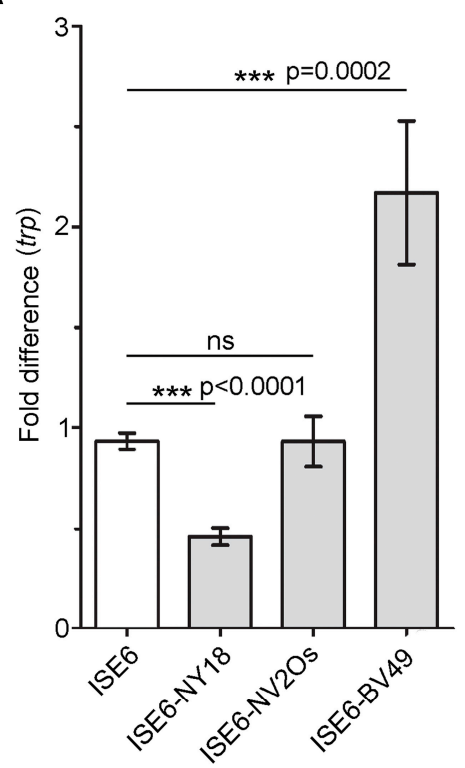

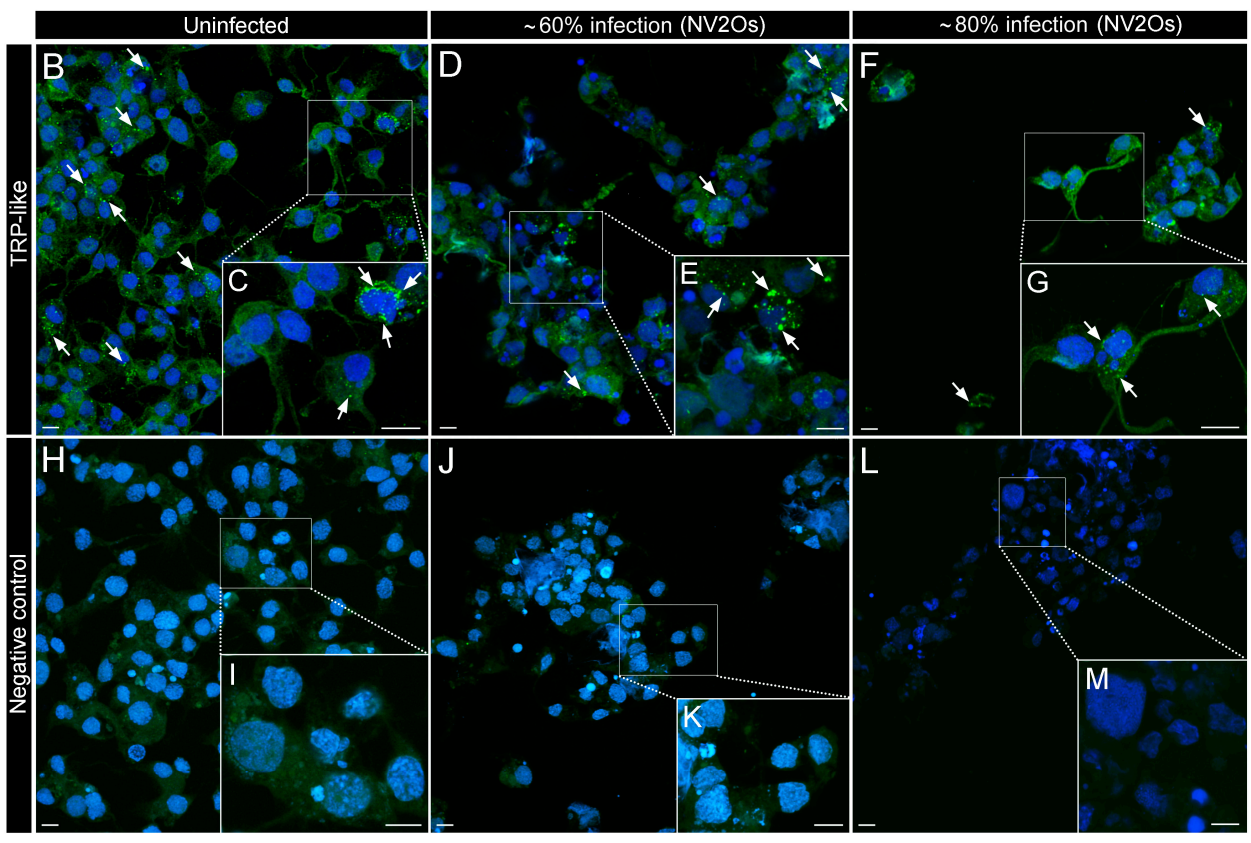

Figure 2. Expression of ISE6 TRP in response to A. phagocytophilum infection. (A) Fold changes in the transcript levels of TRP in the ISE6 cells (y-axis) infected 80\% with three different strains (NY18, NV2Os, and BV49) of A. phagocytophilum (x-axis). The data from three distinct biological replicates were normalized using the rps4 transcript. The asterisk $\left(^{*}\right)$ indicates the comparison of the standard mean error to the uninfected ISE6 value using a one-way Student's $t$-test. (B-G) Immunocytochemistry (ICC) analyses of I. scapularis TRP in uninfected and NV2Os-infected ISE6 cells. (B,C) TRP-like IR (green, arrows) in uninfected cells. Inset in B is magnified in C. The TRP-like IR (green; arrows) for $\approx 60 \%(\mathbf{D}, \mathbf{E})$ and $\approx 80 \%(\mathbf{F}, \mathbf{G})$ infection of the cells with A. phagocytophilum NV2Os strain. Insets in (D) and (F) are magnified in (E) and (G), respectively. (H-M) Negative control staining (i.e., only the secondary antibody was used) for uninfected as well as $\approx 60 \%$ and $\approx 80 \%$ infected cells. Insets in $(\mathbf{H}-\mathbf{L})$ are magnified in (I-M), respectively. Blue labeling are the nuclei $4^{\prime}$,6-diamidino-2-phenylindole (DAPI) staining. Scale bars are $10 \mu \mathrm{m}$. 
Table 1. Neuropeptide genes identified in ISE6 genome sequence and transcript databases. Note that Sequence Read Archive (SRA) corresponds to the Bioproject PRJNA239331 (containing 33 experimental datasets) for Illumina transcript reads. ${ }^{1}$ Possible allelic forms of two scaffolds. ${ }^{2}$ The gene likely spans multiple scaffolds (and multiple predictions); * Incorrect, partially predicted transcript (see Supplementary Figure S2); ND—not detected. Note that XM, XR, and AXL predicted transcripts are from NCBI databases of ISE6 cell and were not detected in VectorBase ISE6 datasets. Nomenclature of the neuropeptides was used according to Coast and Schooley (2011) [51].

\begin{tabular}{|c|c|c|c|}
\hline Neuropeptide Name & Computed Annotation & Scaffold & mRNA (SRA) \\
\hline Adipokinetic hormone/corazonin-related peptide, (ACP) & XR_003917229 & PKSA02006111.1 & $\checkmark$ \\
\hline Achatin-like (GFGE) & XM_029988349 & PKSA02000030.1 & $\checkmark$ \\
\hline Allatostatin CC & ISCI001408 & PKSA02005862.1 & $\checkmark$ \\
\hline Allatotropin & ISCI017791 & PKSA02000866.1 & $\checkmark$ \\
\hline Arginine-vasopressin-like peptide (Inotocin) & XM_029985633 1 & $\begin{array}{l}\text { PKSA02000317.1; } \\
\text { PKSA02014421.1 }\end{array}$ & $\checkmark$ \\
\hline Bursicon alpha & ISCI004617 & PKSA02001242.1 & $\checkmark$ \\
\hline Bursicon beta & ISCI004618 & PKSA02001242.1 & $\checkmark$ \\
\hline Calcitonin-like diuretic hormone 34a & ISCI020490 1 & $\begin{array}{l}\text { PKSA02012946.1; } \\
\text { PKSA02003019.1 }\end{array}$ & $\checkmark$ \\
\hline Calcitonin-like diuretic hormone $34 \mathrm{~b}$ & ISCI009341 & PKSA02005071.1 & $\checkmark$ \\
\hline CCHamide-1 & ISCI013057 & PKSA02001506.1 & $\checkmark$ \\
\hline Corticotropin-releasing factor-related diuretic hormone & ISCI007845 ${ }^{1}$ & $\begin{array}{l}\text { PKSA02003125.1; } \\
\text { PKSA02006996.1 }\end{array}$ & $\checkmark$ \\
\hline Corazonin & ISCI014429 & PKSA02006111.1 & $\checkmark$ \\
\hline Crustacean cardioactive peptide & ISCI010619 & PKSA02006111.1 & $\checkmark$ \\
\hline $\begin{array}{l}\text { Crustacean hyperglycaemic hormone/related ion transport peptide } \\
\text { (CHH/ITP) isoform a }\end{array}$ & ISCI023228 ${ }^{1}$ & $\begin{array}{l}\text { PKSA02003886.1; } \\
\text { PKSA02006116.1 }\end{array}$ & $\checkmark$ \\
\hline $\begin{array}{l}\text { Crustacean hyperglycaemic hormone/related ion transport peptide } \\
\text { (CHH/ITP) isoform b }\end{array}$ & XM_029989718 ${ }^{1}$ & $\begin{array}{l}\text { PKSA02003886.1; } \\
\text { PKSA02006116.1 }\end{array}$ & $\checkmark$ \\
\hline Eclosion hormone & ISCI001941 & PKSA02005732.1 & $\checkmark$ \\
\hline EFLamide & ISCW014582 1 & $\begin{array}{l}\text { PKSA02010407.1; } \\
\text { PKSA02009519.1 } \\
\text { PKSA02008257.1; }\end{array}$ & $\checkmark$ \\
\hline Elevenin & AXL48134.1 1,2 & $\begin{array}{l}\text { PKSA02016953.1 } \\
\text { PKSA02007065.1; } \\
\text { PKSA02009048.1 }\end{array}$ & $\checkmark$ \\
\hline FGLa-related allatostatin (Allatostatin A) & ISCI022939 1 & $\begin{array}{l}\text { PKSA02013181.1; } \\
\text { PKSA02004535.1 }\end{array}$ & $\checkmark$ \\
\hline Glycoprotein A2 & XM_029991759 1 & $\begin{array}{l}\text { PKSA02013868.1; } \\
\text { PKSA02004257.1 }\end{array}$ & $\checkmark$ \\
\hline Glycoprotein B5 & ISCI010926 ${ }^{1}$ & $\begin{array}{l}\text { PKSA02004257.1; } \\
\text { PKSA02012429.1 }\end{array}$ & $\checkmark$ \\
\hline Insulin-related peptide 1 & ISCI002549 1 & $\begin{array}{l}\text { PKSA02002782.1; } \\
\text { PKSA02000328.1 }\end{array}$ & $\checkmark$ \\
\hline Insulin-related peptide 2 & ISCW020331 & $\begin{array}{l}\text { PKSA02008623.1; } \\
\text { PKSA02013879.1 }\end{array}$ & $\checkmark$ \\
\hline PISCF-related allatostatin (Allatostatin C) & ISCI001803 & PKSA02005862.1 & $\checkmark$ \\
\hline Myoinhibitory peptide (Allatostatin B) & ISCI017595 1 & $\begin{array}{l}\text { PKSA02004180.1; } \\
\text { PKSA02003484.1 }\end{array}$ & $\checkmark$ \\
\hline Kinin & ISCI024200 & PKSA02005591.1 & $\checkmark$ \\
\hline Natalisin & ISCI021632 & PKSA02002188.1 & ND \\
\hline Neuroparsin & XM_0299932151 & PKSA02004554.1 & $\checkmark$ \\
\hline Orcokinin & $\begin{array}{l}\text { ISCI010518 } \\
64.1\end{array}$ & PKSA02003264.1 & $\checkmark$ \\
\hline Proctolin & ISCI005701 1,2 & $\begin{array}{l}\text { PKSA02003526.1; } \\
\text { PKSA02018840.1 } \\
\text { PKSA02018839.1 }\end{array}$ & $\checkmark$ \\
\hline Prothoracicotropic hormone-like (Trunk) & ISCI001809 & PKSA02005517.1 & $\checkmark$ \\
\hline Pyrokinin & ISCI019582 & PKSA02005732.1 & $\checkmark$ \\
\hline RYamide & ISCI005825 & PKSA02000030.1 & $\checkmark$ \\
\hline SIFamide & ISCI022950 & PKSA02005457.1 & $\checkmark$ \\
\hline Short neuropeptide F & ISCI007409 & PKSA02002025.1 & $\checkmark$ \\
\hline Sulfakinin & XM_029979447 & PKSA02001743.1 & $\checkmark$ \\
\hline Tachykinin related peptide (TRP) & ISCI008383* & PKSA02005591.1 & $\checkmark$ \\
\hline Trissin & ISCI011258 & PKSA02005519.1 & $\checkmark$ \\
\hline
\end{tabular}


The ICC revealed cytoplasmic TRP-like IR in the majority of uninfected ISE6 cells (Figure 2B,C). Although processes such as axon-like filopodia were apparent in a predominant cell subpopulation of both uninfected and infected ISE6 cells, these filopodia were absent of any TRP-like IR (Figure 2B-G). The levels of NV2Os used (60\% and $80 \%$ ) are considered a high infection status that may cause a decrease in cell population-as qualified by cells infected with $80 \%$ NV2Os compared to uninfected and 60\% infection (Figure 2D-G). As expected by the stable trp transcript levels, and comparable to uninfected cells (Figure 2A), cytoplasmic TRP-like IR was also observed in ISE6 cells from both NV2Os infection levels (Figure 2D-G). However, there are more compact clusters of TRP-like IR in uninfected and 60\% NV2Osinfected cells than at $80 \%$ infection (Figure $2 \mathrm{~B}-\mathrm{G}$ ). Negative control in uninfected and infected cells did not reveal any TRP-like IR (Figure 2H-M).

\subsection{Expression of TRP in I. scapularis Synganglion}

The in situ hybridization (ISH) determined trp transcript distribution in specific neurons of the I. scapularis synganglion (Figure 3A,B). Each positively labeled neuron is represented as the first two letters of a specific synganglion lobe: prothocerebral $(\mathrm{Pc})$, pedal ganglion 1-4 (Pd1-4), opisthosomal ganglion (Os). The letters that follow refer to the anatomical location of the neuron: dorsal $(\mathrm{D})$, ventral $(\mathrm{V})$, anterior $(\mathrm{A})$, posterior $(\mathrm{P})$, medial (M), or lateral (L). The Pc trp transcripts are expressed in three pairs of small PcAM neurons, two pairs of small PcDL 1,2 neurons, and one pair of small PcDM neurons. The trp signal in the Pd1 was detected in a prominent pair of large $\mathrm{Pd}_{1} \mathrm{DL}$ neurons surrounded by two pairs of smaller $\mathrm{Pd}_{1} \mathrm{DL}_{1,2}$ and $\mathrm{Pd}_{1} \mathrm{VL}_{1,2}$ neurons. The trp signal was also detected in the $\mathrm{Pd} 3$ by a small pair of neurons in the $\mathrm{Pd}_{3} \mathrm{DM}$ and the $\mathrm{Pd}_{3} \mathrm{VL}_{1,2}$. Strong trp transcript signals identified on the dorsal side of the Os were expressed by two pairs of OsDM and $\mathrm{OsDM}_{1}$ neurons, while signals from the ventral side were detected by three pairs of $\mathrm{OsVM}_{1-3}$ neurons.

The immunohistochemistry (IHC) confirms the ISH reaction in neurons of the PcAM, $\mathrm{Pd}_{1} \mathrm{DL}, \mathrm{Pd}_{3} \mathrm{VL}_{1}, \mathrm{OsDM}$, and $\mathrm{OsDM}_{1}$ (Figure $3 \mathrm{C}, \mathrm{D}$ ). A strong TRP-like IR was detected in the axons exiting the prominent $\mathrm{Pd}_{1} \mathrm{DL}$ neurons. These axons run from the $\mathrm{Pd}_{1} \mathrm{DL}$ neuronal bodies toward the esophagus, turning laterally about the level of the second pedal ganglion and arborize into a rich axonal network on the synganglion surface (Figure 3C,I). The TRP-like axons of the lateral nerves and their three hemal branches originate from unidentified neurons of the Os (Figure 3E-I). The TRP-like axons in hemal nerves 1 and 2 run alongside the lateral segmental organs (LSO) (Figure 3E-G). TRP-like IR was scattered in all four intrinsic LSO cells. The most prominent reactions in two LSO cells are in contact zones with the TRP-like axons (Figure 3F,G). TRP-like axons exiting the synganglion were also detected in all four pairs of nerves exiting the Os (Figure 3H,I). Scattered TRP-like IR was detected in axons terminating on the dorsal surface of periganglionic sheath. The origin of this axons are likely $\mathrm{Pd}_{1} \mathrm{DL}$ neurons. 


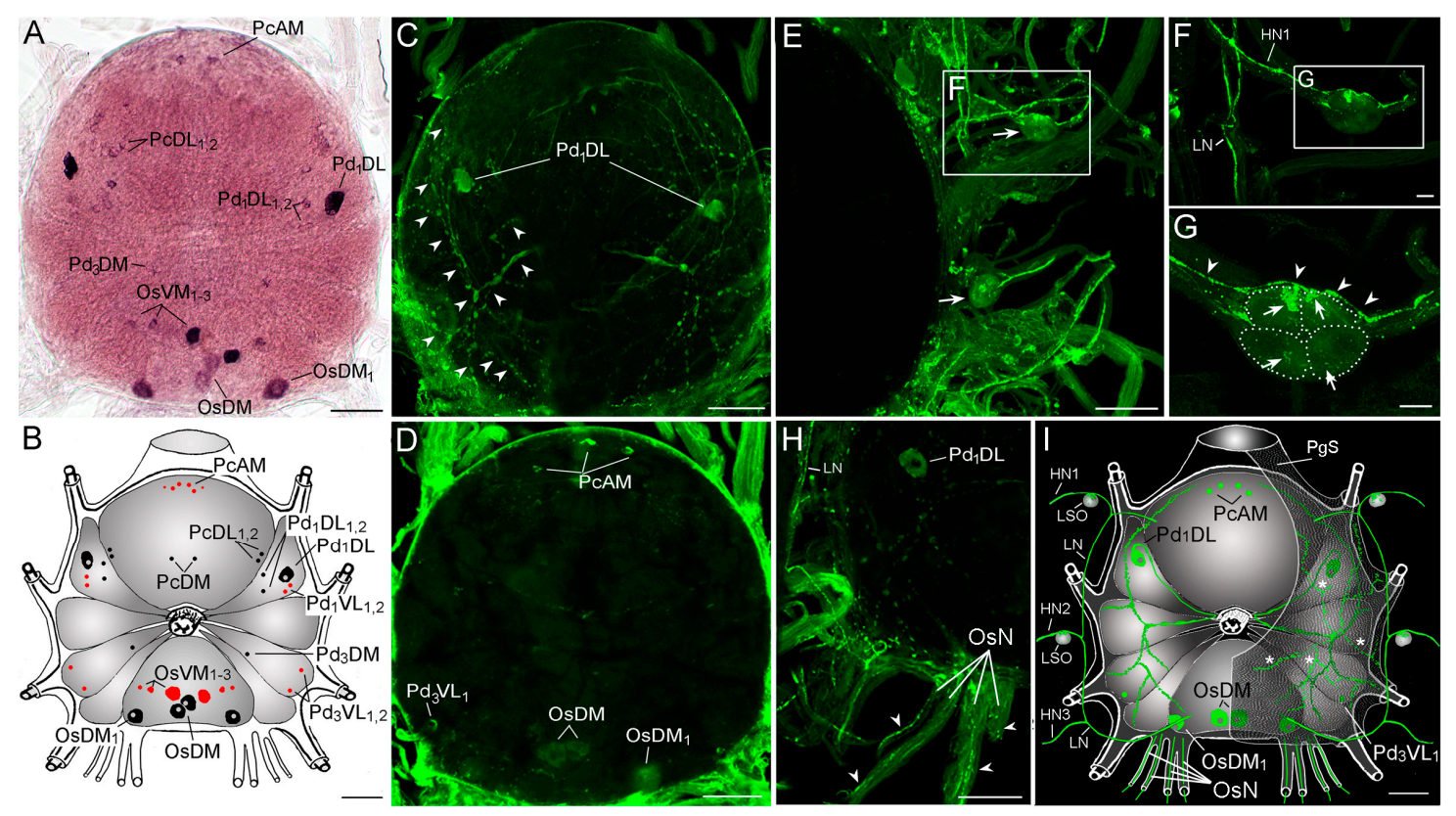

Figure 3. Wholemount trp in situ hybridization (ISH) and TRP immunohistochemistry (IHC) in synganglion from I. scapularis unfed female. (A) ISH staining with TRP antisense probe and schematic drawing in (B). In the schema (B), ISH-stained dorsal neurons are colored in black and ventral neurons are colored in red. (C) TRP-like IR (green) in I. scapularis synganglion. Arrowheads show the axonal projections originating from $\mathrm{Pd}_{1}$ DL neurons. (D) Different Z-stack positions of the synganglion highlighting the TRP-like IR (green) neurons. (E) Lateral side of the synganglion highlighting the TRP-like IR (green) lateral nerve (LN) and associated lateral segmental organs (arrows). (F-G) Magnified view of the lateral segmental organs (LSO). Arrows in G show the TRP-like IR in cells of LSO, while arrowheads show the TRP-like axon within the hemal nerve 1 (HN1), running along the LSO. Dotted lines in G show the boundaries of the different LSO cells. (H) Lateral posterior part of the synganglion with associated nerves. Arrowheads show the TRP-like IR axons in four pairs of opisthosomal nerves (OsN), (I) Schematic drawing of I. scapularis synganglion summarizing all detected TRP-like IR (green) including neurons and axonal projections. Hemal nerves 1-3 (HN1-3), periganglionic sheath (PgS). Asterisks indicate TRP-like IR in axon terminals on dorsal surface of PgS. Scale bar for A-E is $50 \mu \mathrm{m}$, for F, G is $10 \mu \mathrm{m}$ and for $\mathrm{H}, \mathrm{I}$ is $50 \mu \mathrm{m}$.

\section{Discussion}

The relationships between ticks and TBPs are complex, and understanding their molecular determinants is crucial for developing effective control strategies. Here, we introduce the existence of neuropeptide transcripts in ISE6 cells and present their neuropeptidergic features. These findings are supported by previous studies indicating that ISE6 cells are predominantly neuron-like [18].

The in silico prediction of neuropeptide genes from the ISE6 cell genome [52] reveals the same set of genes identified in the I. scapularis genome [37,43], but previous proteomic approaches failed to identify mature neuropeptides in ISE6 cells [18]. In the current study, we confirmed the expression of a complete Ixodes neuropeptidome in ISE6 cells. Considering that neuropeptides are regulators of all tick physiological processes and pathogens modulate tick physiology [32], our study suggests that ISE6 cells are an effective in vitro archetype for investigating TBP interactions with vital elements (i.e., neuropeptides) of the tick synganglion. Therefore, investigating tick-pathogen interactions by enlisting parallel, yet similar, cell-types (i.e., ISE6 cells and tick synganglion) may contribute to advancing tick control strategies to prevent TBP transmission. Attempts have been made to exploit components of the tick nervous system for control measures, but these studies did not achieve any information for pathogen infection or transmission [53-55].

Our ICC analyses detect distinct TRP-like IR in ISE6 cells, indicating the effective translation process of trp transcripts. It is not known whether the TRP-like IR in ISE6 cells is specific to neuropeptide epitopes within the prepropeptide, propeptide, or mature 
neuropeptides. However, evidence shows that mature neuropeptides are transported via the axons to their terminals [41], while pre/propeptides, theoretically, are proximate to the cell cytoplasm. Our study shows that TRP-like IR was strictly localized within the cytoplasm of ISE6 cells, while no staining was expressed in the axon-like filopoda. The ISE6 cells develop axon-like projections under unknown factors in the hemocoel of partially fed ticks [18]. Therefore, an interesting examination is if these unknown factors facilitate the axonal guidance of specific neuropeptidergic-type ISE6 cells. The subsequent immunodetection of additional neuropeptides may also elucidate the qualitative distribution of neuropeptidergic-type ISE6 cells.

The African species Rhipicephalus appendiculatus was the first tick experimentally used to confirm TRP-like IR in synganglion neurons [38]. The $R$. appendiculatus $\mathrm{Pd}_{1} \mathrm{SG}$ neurons are named $\mathrm{Pd}_{1} \mathrm{DL}$ neurons in I. scapularis where we localized, among other synganglion cells, trp transcripts using ISH. Our IHC approach confirms TRP-like IR in the majority of ISH synganglion stained cells, thereby highlighting specific I. scapularis TRP-producing neurons. The molecular characterization of the I. ricinus TRP encoding sequence also confirms an evolutionary relationship with the I. scapularis TRP previously identified [56] and verified here. The commonality in TRP-like expression for R. appendiculatus and I. scapularis synganglion, and the sequence identity of two out of three mature TRP between I. scapularis, I. ricinus, $R$. microplus, $R$. sanguineus and D. silvarum, suggests common attributes of TRP signaling in hard tick lineage.

In addition to the TRP-like IR in neuronal bodies, we identified several TRP-like IR axons exiting the I. scapularis synganglion, suggesting multiple visceral targets for TRPaxonal signaling. Localized TRP-like IR in LSOs, and their associated axons, supports previous findings that LSO cells are peptidergic and/or serve as neurohemal sites [37,38]. Furthermore, the arborization of TRP-like axon terminals on the paraganglionic sheath of the dorsal synganglion surface suggests a possible neurohemal site for discharging TRP to the hemolymph-thereby acting as neurohormones. Knowledge on TRP roles in ticks may help to localize their cognate receptors. The Ixodes genome possesses 10 putative TRP receptors (TRP-Rs) [43], whereas insects, at most, possess two TRP-Rs per species [57]. Since a TRP function in insects is diuresis [57], the increased number of Ixodes TRP-Rs may reflect the acute need for eliminating excess water and metabolic waste during tick feeding. However, whether these Ixodes TRP-Rs are functional and/or possess affinity to TRP ligands awaits experimental confirmation.

A. phagocytophilum induces tissue-specific transcriptional reprogramming, thereby affecting different cellular functions in infected tick [21-23,26-28]. A. phagocytophilum infection also alters tick physiology and behavior [32]. For example, A. phagocytophilum-infected ticks were more fitted to survive in cold temperatures [34] or desiccating conditions [35] compared to uninfected ticks. The differential regulation of heat shock protein transcripts (i.e., hsp20 and $h s p 70$ ) upon A. phagocytophilum infection in ticks was associated with an increase in questing activity [35]. Our present study shows that trp levels in ISE6 cells are differentially regulated in response to infection by different $A$. phagocytophilum strains with specificities for bovine (BV49), ovine (NV2Os), or human (NY18) hosts. Although the precise molecular mechanism(s) by which particular A. phagocytophilum strains interact with TRP is unknown, our data suggest that $A$. phagocytophilum modulates TRP transcript levels in a strain-specific manner. Invertebrate TRPs have multiple functions in the central nervous system and intestine [48], but the specific functions of many tick neuropeptides have yet to be determined. Therefore, investigations are necessary to conclude if A. phagocytophilum affects TRP expression in infected ticks and thus alter their physiology.

Future research will confirm if other neuropeptide transcripts differentially respond to the presence of Anaplasma to elucidate the complex cascade of physiological features potentially modified by this pathogen. We anticipate that identifying the crucial neuronal components in tick-pathogen interactions will present key targets for developing novel tick management strategies applicable to a broad spectrum of TBPs. Thereby, these novel strategies will reduce the negative impacts TBPs have on human and animal health. 


\section{Materials and Methods}

\subsection{In Silico Identification of Neuropeptides Genes in ISE6 Databases}

We used 34 I. scapularis preproneuropeptide query sequences previously identified in the genome project [43]. The list of queries was enriched by previously identified I. scapularis neuropeptide sequences natalisin [49] and elevenin [58], and the insulin-like peptide 2, identified using Drosophila subobscura sequence (GenBank access. no. XP_034657457.1). In addition, an isoform $\mathrm{b}$ of I. scapularis crustacean hyperglycemic hormone-( $\mathrm{CHH})$-related ion transport peptide (CHH/ITP) was also included to the query list. Thus, 38 preproneuropeptides were BLAST against publicly available ISE6 cell line databases in NCBI (www.ncbi.nlm.nih.gov) and VectorBase (www.vectorbase.org) to identify a computed predicted transcript of homologous neuropeptides. To identify genomic scaffolds encoding neuropeptides, VectorBase databases were exclusively used for BLAST. To reveal the expressed neuropeptide transcripts in ISE6 cells, we provided homology BLAST searches of the ISE6 Sequence Read Archive (SRA) in BioProject PRJNA239331 that contains 33 experimental datasets from Illumina transcript reads.

\subsection{Culture of ISE6 Cells}

The ISE6 embryonic tick cell cultures were maintained according to Munderloh et al. [17]. Healthy, uninfected ISE6 cells were propagated in a flask of $25 \mathrm{~cm}^{2}$ with $5 \mathrm{~mL}$ of L15B300 medium. Infected cells were cultured in L15B300 medium supplemented with $0.1 \% \mathrm{NaHCO}_{3}$ and $10 \mathrm{mM}$ HEPES with an adjusted $\mathrm{pH}$ at 7.5. Both uninfected and infected ISE6 cells were maintained at $34{ }^{\circ} \mathrm{C}$.

\subsection{Neuropeptides Quantitative Real-Time PCR in ISE6 Cells}

Total RNA was extracted from ISE6 cells by Trizol Reagent (Invitrogen, Carlsbad, CA, USA) and complementary DNA (cDNA) was obtained by reverse transcription using the High Capacity cDNA Reverse Transcription kit (Invitrogen, Carlsbad, CA, USA). The template cDNAs were analyzed for amplification using the SYBR Green Master Mix (Roche, Basel, Switzerland) on a LightCycler ${ }^{\circledR} 480$ thermocycler (Roche, Basel, Switzerland). The primers for quantitative RT-PCR (qRT-PCR) are listed in Supplementary Table S1. Then, relative transcript levels were calculated using the $\Delta \Delta C t$ ratio [59]. The ribosomal protein S4 (rps4) (GenBank accession number DQ066214) was used as a reference gene [60]. The statistical significance of normalized $\mathrm{Ct}$ values between groups was evaluated by Student's $t$-test with unequal variance in the GraphPad 5 Prism program (GraphPad Software Inc., San Diego, CA, USA). Differences were considered significant when $p<0.05$. Three technical and two biological replications were performed.

\subsection{Gene Cloning and Sequence Analyses}

The I. scapularis EST sequence (EL516783) [44] was used to amplify the full open reading frame (ORF) of I. ricinus TRP. The forward and reverse primers used for amplifica-

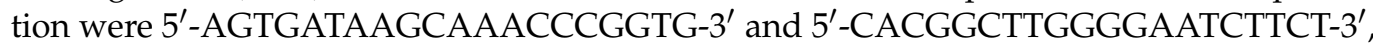
respectively. The predicted full-length ORF of $\operatorname{tr} p$ was amplified by PCR using CDNA isolated from unfed I. ricinus adult synganglia. The PCR amplicon of trp ORF was inserted into the pGEM-T Easy vector (Promega) followed by the transformation of competent DH5 $\alpha$ bacteria (prepared using the Mix \& Go kit, Zymo Research). Plasmid DNA was purified using the Nucleospin Plasmid kit (Macherey-Nagel, Düren, Germany). Recombinant plasmids were commercially sequenced (Eurofins, Luxemburg). We used the Signal P3.0 server to predict the signal peptide of TRP precursor [61].

\subsection{Pathogen Infection of ISE6 Cells}

Either the A. phagocytophilum bovine strain BV49 [62], ovine strain NV2Os [63], or human strain NY18 [64] were propagated in ISE6 tick cells as described before [19]. A. phagocytophilum infection was propagated by transferring 1/10th of an infected ISE6 cell culture to a new flask of healthy cells once infection reached $70 \%$. To determine the level of infection, 
$300 \mu \mathrm{L}$ of media with $100 \mu \mathrm{L}$ of suspended cells were mixed, and $60 \mu \mathrm{L}$ of the mixture were concentrated on a slide using the Shandon Cytospin (Thermo Fisher Scientific, Kalamazoo, MI, USA). Subsequently, the Hemacolor ${ }^{\circledR}$ staining kit (Merck, Darmstadt, Germany) provided observation of cells under an Olympus BX53 light microscope (Olympus, Hamburg, Germany).

\subsection{Immunocytochemistry of TRP in Uninfected and A. phagocytophilum-Infected ISE6 Cells}

The cells were cultured in tubes of $7 \mathrm{~cm}^{2}$ with $1 \mathrm{~mL}$ of L15B300 medium. Trac bottles containing internal glass slides (Dutscher, Brumath, France) were maintained at $34{ }^{\circ} \mathrm{C}$ as described in the section above. After one week, cells attached on the glass slides were washed with phosphate-buffered saline (PBS, $137 \mathrm{mM} \mathrm{NaCl}, 1.45 \mathrm{mM} \mathrm{NaH} \mathrm{PO}_{4} . \mathrm{H} 2 \mathrm{O}, 20.5 \mathrm{mM}$ $\mathrm{Na}_{2} \mathrm{HPO}_{4}, \mathrm{pH} 7.2$ ) and fixed for $30 \mathrm{~min}$ at room temperature (RT) in $4 \%$ paraformaldehyde. After three washes with PBS $+0.01 \%$ Triton X-100 (PBST), cells were incubated at $4{ }^{\circ} \mathrm{C}$ overnight with anti-rabbit antibody (diluted 1:1000 in PBST) against D. melanogaster TRPlike neuropeptide, natalisin 4 (DromeNTL4) [50]. Then, the cells were washed three times for 5 min with PBST and incubated in dark conditions for $3 \mathrm{~h}$ at RT with goat anti-rabbit Alexa 488 conjugated secondary antibody (Life technologies) diluted at 1:1000. After three PBST washes, the cells were mounted in antifade media containing DAPI for nuclei staining (ProLong ${ }^{\mathrm{TM}}$ Diamond Antifade Mountant with DAPI, Thermo Fisher). The immunoreaction was observed under a Leica DMi8 confocal microscopy. The images were assembled in Adobe Photoshop CS4 (Adobe, Mountain View, CA, USA).

\subsection{In Situ Hybridization}

Validated ISH protocol previously developed by Šimo et al. [45,65] for tick synganglia was used. Briefly, a digoxygenin (DIG) probe synthesis kit (Roche Diagnostic, Germany) was used to synthesize a single-stranded DIG-labeled DNA probe for trp (662 bp). The I. ricinus trp ORF insert in the pGM-T Easy plasmid was used as a template (see the section Gene cloning and sequence analyses in Materials and Methods). Asymmetric PCR using either reverse (5'-CACGGCTTGGGGAATCTTCT-3') or forward (5'-AGTGATAAGCAAACCCGGTG-3') primer was performed to generate respective antisense and sense probes. Synthesized DIGlabeled probes were gel-purified and stored at $-20^{\circ} \mathrm{C}$. Synganglia of unfed I. scapularis females were dissected in cold PBS and fixed with $4 \%$ paraformaldehyde for $2 \mathrm{~h}$ at RT. After cell membrane permeabilization with Proteinase K (New England BioLabs), synganglia were incubated with single-stranded DIG-DNA probes for $27 \mathrm{~h}$ at $48{ }^{\circ} \mathrm{C}$. Then, specimens were incubated with mouse anti-digoxygenin/AP (Alkaline phosphatase; Roche Diagnostics, Germany) overnight at $4{ }^{\circ} \mathrm{C}$. The reaction with hybridized DIG probes was developed by the addition of substrate/chromogen ready-to-use NBT-BCIP tablets (Roche Diagnostics, Germany). Finally, samples were incubated $5 \mathrm{~min}$ in 50\% glycerol and subsequently mounted into 100\% glycerol and observed by light microscopy (Olympus BX53). Images were assembled and enhanced in Adobe Photoshop CS4.

\subsection{Wholemount Immunohistochemistry of Ixodes Synganglion}

We slightly modified the IHC protocols previously described by Šimo et al. [38,45,47]. Briefly, Ixodes synganglia were dissected from unfed adult females, fixed with $4 \%$ paraformaldehyde solution for $2 \mathrm{~h}$ at RT, and then washed with PBS $+0.5 \%$ Triton X-100 (PBST). Tissues were incubated for 3 days at $4{ }^{\circ} \mathrm{C}$ with polyclonal anti-rabbit antibody against D. melanogaster NTL4 diluted 1:1000 in PBST. After three washes in PBST, the specimens were incubated two days at $4{ }^{\circ} \mathrm{C}$ with a goat anti-rabbit Alexa 488 conjugated secondary antibody (Life technologies) diluted at 1:1000. Samples were mounted in Prolong Antifade Diamond Mountant containing DAPI (Life Technologies) and analyzed by a Leica DMi8 confocal microscopy. Image assemblage was performed in Adobe Photoshop CS4. For neuronal cells of tick synganglia, we used nomenclatures as per Šimo et al. [38]. 
Supplementary Materials: The following are available online at https: / www.mdpi.com/2076-0 $817 / 10 / 1 / 70 /$ s1, Figure S1: Relative expression of ribosomal protein S4 (rps4) transcript and six different neuropeptide transcripts in uninfected ISE6 cells, Figure S2: Protein (A) and nucleotide (B) alignment of Ixodes scapularis and Ixodes ricinus TRP, Table S1: List of primers used in our qRT-PCR experiments.

Author Contributions: Conceptualization, L.M.-H., A.C.-C. and L.Š.; formal analysis, L.M.-H., N.P., E.A., A.C.-C. and L.Š.; investigation, L.M.-H., N.P., E.A., C.R. and L.Š.; resources, C.H., A.-C.L., N.H., H.-J.B., P.A., J.d.l.F., A.C.-C. and L.Š.; writing-original draft preparation, L.M.-H., J.J.V., A.C.-C. and L.Š.; writing-review and editing, L.M.-H., N.P., E.A., C.H., C.R., A.-C.L., H.-J.B., J.J.V., P.A., J.d.1.F., A.C.-C. and L.Šs; supervision, A.C.-C. and L.Š.; funding acquisition, A.C.-C. and L.Š. All authors have read and agreed to the published version of the manuscript.

Funding: This research was funded by DIM1Health-Région Île-de-France (Acronym of the project: NeuroPaTick), the purchase of confocal microscopy used in this study was supported by the DIM1Health-Région Île-de-France (Acronym of the project: SAMiCAI). The NP was funded by French Institute of Slovakia/French embassy of Slovakia, the JJV was supported by Project FIT (Pharmacology, Immunotherapy, nanoToxicology), which was funded by the European Regional Development Fund and acknowledge a grant for the development of a research organization RVO: RO0516.

Institutional Review Board Statement: Not applicable.

Informed Consent Statement: Not applicable.

Data Availability Statement: Not applicable.

Acknowledgments: We thank Snorre Stuen (Norwegian University of Life Sciences) for providing the A. phagocytophilum NV2Os strain. We are also grateful to Erich Peter Zweygarth and Cornelia Silaghi from the Ludwig Maximilians University of Munich for initiating the culture of BV49 A. phagocytophilum strain and providing the culture for our study, respectively. We also thank to Young-Joon Kim from School of Life Sciences, Gwangju Institute of Science and Technology, South Korea for providing the natalisin antibody.

Conflicts of Interest: The authors declare no conflict of interest.

\section{References}

1. Hamer, S.A.; Tsao, J.I.; Walker, E.D.; Hickling, G.J. Invasion of the lyme disease vector Ixodes scapularis: Implications for Borrelia burgdorferi endemicity. Ecohealth 2010, 7, 47-63. [CrossRef] [PubMed]

2. Rizzoli, A.; Silaghi, C.; Obiegala, A.; Rudolf, I.; Hubálek, Z.; Földvári, G.; Plantard, O.; Vayssier-Taussat, M.; Bonnet, S.; Špitalská, E.; et al. Ixodes ricinus and Its Transmitted Pathogens in Urban and Peri-Urban Areas in Europe: New Hazards and Relevance for Public Health. Front. Public Health 2014, 2. [CrossRef]

3. Kocan, K.M.; De la Fuente, J.; Cabezas-Cruz, A. The genus Anaplasma: New challenges after reclassification. Rev. Off. Int. Epizoot. 2015, 34, 577-586. [CrossRef] [PubMed]

4. Kocan, K.M.; De la Fuente, J.; Blouin, E.F.; Garcia-Garcia, J.C. Anaplasma marginale (Rickettsiales: Anaplasmataceae): Recent advances in defining host-pathogen adaptations of a tick-borne rickettsia. Parasitology 2004, 129, S285-S300. [CrossRef] [PubMed]

5. De la Fuente, J.; Antunes, S.; Bonnet, S.; Cabezas-Cruz, A.; Domingos, A.G.; Estrada-Peña, A.; Johnson, N.; Kocan, K.M.; Mansfield, K.L.; Nijhof, A.M.; et al. Tick-Pathogen Interactions and Vector Competence: Identification of Molecular Drivers for Tick-Borne Diseases. Front. Cell. Infect. Microbiol. 2017, 7. [CrossRef] [PubMed]

6. Baldridge, G.D.; Burkhardt, N.Y.; Labruna, M.B.; Pacheco, R.C.; Paddock, C.D.; Williamson, P.C.; Billingsley, P.M.; Felsheim, R.F.; Kurtti, T.J.; Munderloh, U.G. Wide dispersal and possible multiple origins of low-copy-number plasmids in rickettsia species associated with blood-feeding arthropods. Appl. Environ. Microbiol. 2010, 76, 1718-1731. [CrossRef] [PubMed]

7. Munderloh, U.G.; Blouin, E.F.; Kocan, K.M.; Ge, N.L.; Edwards, W.L.; Kurtti, T.J. Establishment of the Tick (Acari: Ixodidae)-Borne Cattle Pathogen Anaplasma marginale (Rickettsiales: Anaplasmataceae) in Tick Cell Culture. J. Med. Entomol. 1996, 33, 656-664. [CrossRef] [PubMed]

8. Munderloh, U.G.; Silverman, D.J.; MacNamara, K.C.; Ahlstrand, G.G.; Chatterjee, M.; Winslow, G.M. Ixodes ovatus Ehrlichia exhibits unique ultrastructural characteristics in mammalian endothelial and tick-derived cells. Ann. N. Y. Acad. Sci. 2009, 1166, 112-119. [CrossRef]

9. Munderloh, U.G.; Yabsley, M.J.; Murphy, S.M.; Luttrell, M.P.; Howerth, E.W. Isolation and establishment of the raccoon Ehrlichialike agent in tick cell culture. Vector Borne Zoonotic Dis. 2007, 7, 418-425. [CrossRef] 
10. Tate, C.M.; Howerth, E.W.; Mead, D.G.; Dugan, V.G.; Luttrell, M.P.; Sahora, A.I.; Munderloh, U.G.; Davidson, W.R.; Yabsley, M.J. Anaplasma odocoilei sp. nov. (family Anaplasmataceae) from white-tailed deer (Odocoileus virginianus). Ticks Tick Borne Dis. 2013, 4, 110-119. [CrossRef]

11. Pornwiroon, W.; Pourciau, S.S.; Foil, L.D.; Macaluso, K.R. Rickettsia felis from Cat Fleas: Isolation and Culture in a Tick-Derived Cell Line. Appl. Environ. Microbiol. 2006, 72, 5589-5595. [CrossRef] [PubMed]

12. Simser, J.A.; Palmer, A.T.; Fingerle, V.; Wilske, B.; Kurtti, T.J.; Munderloh, U.G. Rickettsia monacensis sp. nov., a Spotted Fever Group Rickettsia, from Ticks (Ixodes ricinus) Collected in a European City Park. Appl. Environ. Microbiol. 2002, 68, 4559-4566. [CrossRef] [PubMed]

13. Munderloh, U.G.; Tate, C.M.; Lynch, M.J.; Howerth, E.W.; Kurtti, T.J.; Davidson, W.R. Isolation of an Anaplasma sp. Organism from White-Tailed Deer by Tick Cell Culture. J. Clin. Microbiol. 2003, 41, 4328-4335. [CrossRef] [PubMed]

14. Obonyo, M.; Munderloh, U.G.; Fingerle, V.; Wilske, B.; Kurtti, T.J. Borrelia burgdorferi in Tick Cell Culture Modulates Expression of Outer Surface Proteins A and C in Response to Temperature. J. Clin. Microbiol. 1999, 37, 2137-2141. [CrossRef]

15. Garcia, S.; Billecocq, A.; Crance, J.-M.; Munderloh, U.; Garin, D.; Bouloy, M. Nairovirus RNA Sequences Expressed by a Semliki Forest Virus Replicon Induce RNA Interference in Tick Cells. J. Virol. 2005, 79, 8942-8947. [CrossRef]

16. Grabowski, J.M.; Perera, R.; Roumani, A.M.; Hedrick, V.E.; Inerowicz, H.D.; Hill, C.A.; Kuhn, R.J. Changes in the Proteome of Langat-Infected Ixodes scapularis ISE6 Cells: Metabolic Pathways Associated with Flavivirus Infection. PLoS Negl. Trop. Dis. 2016, 10, e0004180. [CrossRef]

17. Munderloh, U.G.; Liu, Y.; Wang, M.; Chen, C.; Kurtti, T.J. Establishment, maintenance and description of cell lines from the tick Ixodes scapularis. J. Parasitol. 1994, 80, 533-543. [CrossRef]

18. Oliver, J.D.; Chávez, A.S.O.; Felsheim, R.F.; Kurtti, T.J.; Munderloh, U.G. An Ixodes scapularis cell line with a predominantly neuron-like phenotype. Exp. Appl. Acarol. 2015, 66, 427-442. [CrossRef]

19. Alberdi, P.; Mansfield, K.L.; Manzano-Román, R.; Cook, C.; Ayllón, N.; Villar, M.; Johnson, N.; Fooks, A.R.; De la Fuente, J. Tissue-Specific Signatures in the Transcriptional Response to Anaplasma phagocytophilum Infection of Ixodes scapularis and Ixodes ricinus Tick Cell Lines. Front. Cell Infect. Microbiol. 2016, 6, 20. [CrossRef]

20. Artigas-Jerónimo, S.; Alberdi, P.; Rayo, M.V.; Cabezas-Cruz, A.; Prados, P.J.E.; Mateos-Hernández, L.; De la Fuente, J. Anaplasma phagocytophilum modifies tick cell microRNA expression and upregulates isc-mir-79 to facilitate infection by targeting the Roundabout protein 2 pathway. Sci. Rep. 2019, 9, 1-15. [CrossRef]

21. Cabezas-Cruz, A.; Espinosa, P.; Alberdi, P.; De la Fuente, J. Tick-Pathogen Interactions: The Metabolic Perspective. Trends Parasitol. 2019, 35, 316-328. [CrossRef] [PubMed]

22. Shaw, D.K.; Wang, X.; Brown, L.J.; Chávez, A.S.O.; Reif, K.E.; Smith, A.A.; Scott, A.J.; McClure, E.E.; Boradia, V.M.; Hammond, H.L.; et al. Infection-derived lipids elicit an immune deficiency circuit in arthropods. Nat. Commun. 2017, 8, 1-13. [CrossRef] [PubMed]

23. De la Fuente, J.; Villar, M.; Cabezas-Cruz, A.; Estrada-Peña, A.; Ayllón, N.; Alberdi, P. Tick-Host-Pathogen Interactions: Conflict and Cooperation. PLoS Pathog. 2016, 12, e1005488. [CrossRef] [PubMed]

24. Lin, M.; Kikuchi, T.; Brewer, H.M.; Norbeck, A.D.; Rikihisa, Y. Global Proteomic Analysis of Two Tick-Borne Emerging Zoonotic Agents: Anaplasma phagocytophilum and Ehrlichia Chaffeensis. Front. Microbiol. 2011, 2. [CrossRef]

25. Ayllón, N.; Villar, M.; Galindo, R.C.; Kocan, K.M.; Šíma, R.; López, J.A.; Vázquez, J.; Alberdi, P.; Cabezas-Cruz, A.; Kopáček, P.; et al. Systems Biology of Tissue-Specific Response to Anaplasma phagocytophilum Reveals Differentiated Apoptosis in the Tick Vector Ixodes scapularis. PLoS Genet. 2015, 11, e1005120. [CrossRef]

26. Cabezas-Cruz, A.; Alberdi, P.; Valdés, J.J.; Villar, M.; De la Fuente, J. Anaplasma phagocytophilum Infection Subverts Carbohydrate Metabolic Pathways in the Tick Vector, Ixodes scapularis. Front. Cell Infect. Microbiol. 2017, 7, 23. [CrossRef]

27. Cabezas-Cruz, A.; Espinosa, P.J.; Obregón, D.A.; Alberdi, P.; De la Fuente, J. Ixodes scapularis Tick Cells Control Anaplasma phagocytophilum Infection by Increasing the Synthesis of Phosphoenolpyruvate from Tyrosine. Front. Cell Infect. Microbiol. 2017, 7, 375. [CrossRef]

28. Sinclair, S.H.G.; Garcia-Garcia, J.C.; Dumler, J.S. Bioinformatic and mass spectrometry identification of Anaplasma phagocytophilum proteins translocated into host cell nuclei. Front. Microbiol. 2015, 6. [CrossRef]

29. Sinclair, S.H.; Rennoll-Bankert, K.E.; Dumler, J.S. Effector bottleneck: Microbial reprogramming of parasitized host cell transcription by epigenetic remodeling of chromatin structure. Front. Genet. 2014, 5. [CrossRef]

30. Villar, M.; Ayllón, N.; Alberdi, P.; Moreno, A.; Moreno, M.; Tobes, R.; Mateos-Hernández, L.; Weisheit, S.; Bell-Sakyi, L.; De la Fuente, J. Integrated Metabolomics, Transcriptomics and Proteomics Identifies Metabolic Pathways Affected by Anaplasma phagocytophilum Infection in Tick Cells. Mol. Cell Proteom. 2015, 14, 3154-3172. [CrossRef]

31. Cabezas-Cruz, A.; Alberdi, P.; Valdes, J.J.; Villar, M.; De la Fuente, J. Remodeling of tick cytoskeleton in response to infection with Anaplasma phagocytophilum. Front. Biosci. 2017, 22, 1830-1844. [CrossRef]

32. Benelli, G. Pathogens Manipulating Tick Behavior-Through a Glass, Darkly. Pathogens 2020, 9, 664. [CrossRef] [PubMed]

33. Randolph, S.E. Tick ecology: Processes and patterns behind the epidemiological risk posed by ixodid ticks as vectors. Parasitology 2004, 129, S37-S65. [CrossRef] [PubMed]

34. Neelakanta, G.; Sultana, H.; Fish, D.; Anderson, J.F.; Fikrig, E. Anaplasma phagocytophilum induces Ixodes scapularis ticks to express an antifreeze glycoprotein gene that enhances their survival in the cold. J. Clin. Investig. 2010, 120, 3179-3190. [CrossRef] [PubMed] 
35. Busby, A.T.; Ayllón, N.; Kocan, K.M.; Blouin, E.F.; De la Fuente, G.; Galindo, R.C.; Villar, M.; De la Fuente, J. Expression of heat shock proteins and subolesin affects stress responses, Anaplasma phagocytophilum infection and questing behaviour in the tick, Ixodes scapularis. Med. Vet. Entomol. 2012, 26, 92-102. [CrossRef] [PubMed]

36. Lynn, G.E.; Oliver, J.D.; Nelson, C.M.; Felsheim, R.F.; Kurtti, T.J.; Munderloh, U.G. Tissue Distribution of the Ehrlichia muris-Like Agent in a Tick Vector. PLoS ONE 2015, 10. [CrossRef]

37. Šimo, L.; Daniel, S.E.; Park, Y.; Žitňan, D. The Nervous and Sensory Systems: Structure, Function, Proteomics and Genomics. In Biology of Ticks; Sonenshine, D.E., Roe, R.M., Eds.; Oxford University Press: New York, NY, USA, 2014; Volume 1, pp. $309-367$.

38. Šimo, L.; Slovák, M.; Park, Y.; Zitnan, D. Identification of a complex peptidergic neuroendocrine network in the hard tick, Rhipicephalus appendiculatus. Cell Tissue Res. 2009, 335, 639-655. [CrossRef]

39. Hewes, R.S.; Taghert, P.H. Neuropeptides and Neuropeptide Receptors in the Drosophila melanogaster Genome. Genome Res. 2001, 11, 1126-1142. [CrossRef]

40. Caers, J.; Verlinden, H.; Zels, S.; Vandersmissen, H.P.; Vuerinckx, K.; Schoofs, L. More than two decades of research on insect neuropeptide GPCRs: An overview. Front. Endocrinol. 2012, 3. [CrossRef]

41. Yeoh, J.G.C.; Pandit, A.A.; Zandawala, M.; Nässel, D.R.; Davies, S.-A.; Dow, J.A.T. DINeR: Database for Insect Neuropeptide Research. Insect Biochem. Mol. Biol. 2017, 86, 9-19. [CrossRef]

42. Schoofs, L.; De Loof, A.; Van Hiel, M.B. Neuropeptides as Regulators of Behavior in Insects. Annu. Rev. Entomol. 2017, 62, 35-52. [CrossRef]

43. Gulia-Nuss, M.; Nuss, A.B.; Meyer, J.M.; Sonenshine, D.E.; Roe, R.M.; Waterhouse, R.M.; Sattelle, D.B.; De la Fuente, J.; Ribeiro, J.M.; Megy, K.; et al. Genomic insights into the Ixodes scapularis tick vector of Lyme disease. Nat. Commun. 2016, 7, 1-13. [CrossRef] [PubMed]

44. Neupert, S.; Russell, W.K.; Predel, R.; Russell, D.H.; Strey, O.F.; Teel, P.D.; Nachman, R.J. The neuropeptidomics of Ixodes scapularis synganglion. J. Proteom. 2009, 72, 1040-1045. [CrossRef] [PubMed]

45. Šimo, L.; Žitňan, D.; Park, Y. Two novel neuropeptides in innervation of the salivary glands of the black-legged tick, Ixodes scapularis: Myoinhibitory peptide and SIFamide. J. Comp. Neurol. 2009, 517, 551-563. [CrossRef] [PubMed]

46. Vancová, M.; Bílý, T.; Nebesářová, J.; Grubhoffer, L.; Bonnet, S.; Park, Y.; Šimo, L. Ultrastructural mapping of salivary gland innervation in the tick Ixodes ricinus. Sci. Rep. 2019, 9, 1-13. [CrossRef] [PubMed]

47. Šimo, L.; Koči, J.; Park, Y. Receptors for the neuropeptides, myoinhibitory peptide and SIFamide, in control of the salivary glands of the blacklegged tick Ixodes scapularis. Insect. Biochem. Mol. Biol. 2013, 43, 376-387. [CrossRef]

48. Nässel, D.R.; Zandawala, M.; Kawada, T.; Satake, H. Tachykinins: Neuropeptides That Are Ancient, Diverse, Widespread and Functionally Pleiotropic. Front. Neurosci. 2019, 13. [CrossRef]

49. Jiang, H.; Kim, D.; Dobesh, S.; Evans, J.D.; Nachman, R.J.; Kaczmarek, K.; Zabrocki, J.; Park, Y. Ligand selectivity in tachykinin and natalisin neuropeptidergic systems of the honey bee parasitic mite Varroa destructor. Sci. Rep. 2016, 6, 1-8. [CrossRef]

50. Jiang, H.; Lkhagva, A.; Daubnerová, I.; Chae, H.-S.; Šimo, L.; Jung, S.-H.; Yoon, Y.-K.; Lee, N.-R.; Seong, J.Y.; Žitňan, D.; et al. Natalisin, a tachykinin-like signaling system, regulates sexual activity and fecundity in insects. Proc. Natl. Acad. Sci. USA 2013, 110, E3526-E3534. [CrossRef]

51. Coast, G.M.; Schooley, D.A. Toward a consensus nomenclature for insect neuropeptides and peptide hormones. Peptides 2011, 32, 620-631. [CrossRef]

52. Miller, J.R.; Koren, S.; Dilley, K.A.; Harkins, D.M.; Stockwell, T.B.; Shabman, R.S.; Sutton, G.G. A draft genome sequence for the Ixodes scapularis cell line, ISE6. F1000Res. 2018, 7. [CrossRef]

53. Almazán, C.; Šimo, L.; Fourniol, L.; Rakotobe, S.; Borneres, J.; Cote, M.; Peltier, S.; Mayé, J.; Versillé, N.; Richardson, J.; et al. Multiple Antigenic Peptide-Based Vaccines Targeting Ixodes ricinus Neuropeptides Induce a Specific Antibody Response but Do Not Impact Tick Infestation. Pathogens 2020, 9, 900. [CrossRef]

54. Brock, C.M.; Temeyer, K.B.; Tidwell, J.; Yang, Y.; Blandon, M.A.; Carreón-Camacho, D.; Longnecker, M.T.; Almazán, C.; Pérez de León, A.A.; Pietrantonio, P.V. The leucokinin-like peptide receptor from the cattle fever tick, Rhipicephalus microplus, is localized in the midgut periphery and receptor silencing with validated double-stranded RNAs causes a reproductive fitness cost. Int. J. Parasitol. 2019, 49, 287-299. [CrossRef] [PubMed]

55. Opdebeeck, J.P.; Wong, J.Y.; Jackson, L.A.; Dobson, C. Vaccines to protect Hereford cattle against the cattle tick, Boophilus microplus. Immunology 1988, 63, 363-367. [PubMed]

56. Christie, A.E. Neuropeptide discovery in Ixodoidea: An in silico investigation using publicly accessible expressed sequence tags. Gen. Comp. Endocrinol. 2008, 157, 174-185. [CrossRef] [PubMed]

57. Park, Y. Endocrine regulation of insect diuresis in the early postgenomic era1. Can. J. Zool. 2012. [CrossRef]

58. Kim, D.; Šimo, L.; Park, Y. Molecular characterization of neuropeptide elevenin and two elevenin receptors, IsElevR1 and IsElevR2, from the blacklegged tick, Ixodes scapularis. Insect. Biochem. Mol. Biol. 2018, 101, 66-75. [CrossRef] [PubMed]

59. Livak, K.J.; Schmittgen, T.D. Analysis of relative gene expression data using real-time quantitative PCR and the 2(-Delta Delta C(T)) Method. Methods 2001, 25, 402-408. [CrossRef]

60. Koči, J.; Šimo, L.; Park, Y. Validation of Internal Reference Genes for Real-Time Quantitative Polymerase Chain Reaction Studies in the Tick, Ixodes scapularis (Acari: Ixodidae). J. Med. Entomol. 2013, 50, 79-84. [CrossRef]

61. Emanuelsson, O.; Brunak, S.; Von Heijne, G.; Nielsen, H. Locating proteins in the cell using TargetP, SignalP and related tools. Nat. Protoc. 2007, 2, 953-971. [CrossRef] 
62. Silaghi, C.; Nieder, M.; Sauter-Louis, C.; Knubben-Schweizer, G.; Pfister, K.; Pfeffer, M. Epidemiology, genetic variants and clinical course of natural infections with Anaplasma phagocytophilum in a dairy cattle herd. Parasites Vectors 2018, 11, 20. [CrossRef] [PubMed]

63. Stuen, S.; Van De Pol, I.; Bergström, K.; Schouls, L.M. Identification of Anaplasma phagocytophila (Formerly Ehrlichia phagocytophila) Variants in Blood from Sheep in Norway. J. Clin. Microbiol. 2002, 40, 3192-3197. [CrossRef] [PubMed]

64. Asanovich, K.M.; Bakken, J.S.; Madigan, J.E.; Rosenfeld, M.A.; Wormser, G.P.; Dumler, J.S. Antigenic Diversity of Granulocytic Ehrlichia Isolates from Humans in Wisconsin and New York and a Horse in California. J. Infect. Dis. 1997, 176, 1029-1034. [CrossRef] [PubMed]

65. Mateos-Hernandéz, L.; Defaye, B.; Vancová, M.; Hajdusek, O.; Sima, R.; Park, Y.; Attoui, H.; Šimo, L. Cholinergic axons regulate type I acini in salivary glands of Ixodes ricinus and Ixodes scapularis ticks. Sci. Rep. 2020, 10, 1-15. [CrossRef] [PubMed] 